\title{
DASAR-DASAR KETERAMPILAN MENGAJAR MATEMATIKA
}

\author{
Mariam Nasution \\ Fakultas Tarbiyah dan IImu Keguruan IAIN Padangsidimpuan \\ Jalan T.Rizal Nurdin Sihitang Padangsidimpuan
}

\begin{abstract}
Abstrak
Seorang guru matematika yang efektif adalah guru yang berhasil membawa peserta didiknya mencapai tujuan pembelajaran dan sesuai kaidah yang berlaku dalam pendidikan. Untuk mencapai tingkat efektifitas pembelajaran matematika guru mempunyai fungsi sebagai narasumber, demonstrator, pengelola kelas, mediator, fasilitator, dan evaluator. Guru harus menguasai berbagai keterampilan dasar mengajar yang meliputi: keterampilan membuka dan menutup pelajaran, keterampilan menjelaskan, keterampilan bertanya, keterampilan menggunakan variasi mengajar, keterampilan memberi penguatan, keterampilan mengajar kelompok kecil, keterampilan mengelola kelas, dan keterampilan membimbing diskusi kecil. Dengan demikian seorang guru matematika harus mempunyai keterampilan dasar mengajar. Ini sangat penting sebagai syarat menjadi seorang guru. Seorang guru professional harus mengikuti beberapa pelatihan yang berkaitan dengan keterampilan dasar mengajar agar fungsi pengajaran tercapai dengan baik.
\end{abstract}

\begin{abstract}
An effective mathematics teacher is a teacher who managed to bring learners to achieve the learning objectives according to the rules in force in education. To achieve the level of effectiveness of learning math, the teacher has the function as a resource, demonstrator, manager of the class, mediator, facilitator and the evaluator. The teacher must master the basic skills of teaching which include: opening and closing skills lesson, explaining skills, questioning skills, skills using a variation of teaching, provide reinforcement of skills, small group teaching skills, classroom management skills and skills to initiate discussion. Thus, a math teacher should have the basic skills in teaching. It is very important as a condition of becoming a teacher. A professional teacher should follow some training related to teaching basic skills in order to function properly accomplished teaching.
\end{abstract}

\section{Kata Kunci: Keterampilan, Mengajar, Matematika}




\section{Pendahuluan}

Proses belajar-mengajar merupakan suatu proses yang mengandung serangkaian perbuatan guru dan siswa atas dasar hubungan timbal balik yang berlangsung dalam situasi edukatif untuk mencapai tujuan tertentu. Interaksi atau hubungan timbal-balik antara guru dan siswa itu merupakan syarat utama bagi berlangsungnya proses belajar-mengajar. Dalam proses belajar-mengajar dituntut seorang guru yang profesional. Menurut Surya guru profesional akan tercermin dalam pelaksanaan pengabdian tugas-tugas yang ditandai dengan keahlian baik dalam materi maupun metode. ${ }^{1}$ Selain itu ditunjukkan melalui tanggung jawabnya dalam melaksanakan pengabdiannya.

Guru professional mempunyai tanggung jawab pribadi, sosial, intelektual, moral, dan spiritual. Tanggung jawab pribadi yang mandiri yang mampu memahami dirinya mengelola dirinya, mengendalikan dirinya dan menghargai serta mengembangkan dirinya. Tugas guru sebagai profesi meliputi mendidik, mengajar,dan melatih. Mengajar berarti meneruskan dan mengembangkan ilmu pengetahuan dan teknologi. Melatih berarti mengembangkan keterampilan pada siswa. Disamping itu seorang guru harus mengetahui teknik-teknik mengajar sebagai pedoman untuk menyampaikan informasi yang di anggap penting.

Keterampilan seorang guru yang harus dikuasai seorang pendidik yaitu keterampilan dasar mengajar. Apabila seorang guru tidak mempunyai keterampilan dasar mengajar, maka guru tersebut tidak dapat berhasil untuk mencapai tujuan pembelajaran. Dengan demikian, seorang guru bukan hanya mempunyai wawasan keilmuwan yang luas tetapi harus dapat melaksanakan proses belajar-mengajar dengan baik dengan tidak meninggalkan aspek keterampilan dasar mengajar.

\section{Peran Guru dalam Proses Pembelajaran Matematika}

Belajar matematika berkaitan dengan apa dan bagaimana menggunakan kemampuan dalam membuat keputusan untuk memecah-

1 Muhammad Surya, Membangun Manusia Profesioalisme Guru, Makalah Seminar Pendidikan, Jakarta, 6 Mei 2005. 
kan masalah matematika dengan melibatkan pengamatan, penyelidikan dan keterkaitannya dengan fenomena fisik dan sosial. Belajar matematika merupakan suatu kegiatan yang berkenaan dengan penyelesaian himpunan-himpunan dari unsur matematika yang sederhana dan himpunan-himpunan baru yang lebih rumit. Demikian seterusnya sehingga dalam belajar matematika pada tahap yang lebih tinggi, yang didasarkan pada tahap belajar yang lebih rendah. Sedangkan karakteristik matematika terletak pada kekhususan dalam mengkomunikasikan matematika melalui bahasa numeric. Dengan bahasa numeric memung-kinkan seseorang dapat melakukan pengukuran secara kuantitatif, sedang sifat kekuantitatifan dari matematika tersebut dapat memberikan kemudahan bagi seseorang dalam menyikapi suatu masalah. ${ }^{2}$

Berkaitan dengan karakteristik matematika, maka seorang guru harus mampu meningkatkan perannya dalam meningkatkan kualitas pembelajaran matematika. Guru yang mempunyai kompeten akan lebih mampu menciptakan lingkungan belajar yang efektif dan akan lebih mampu mengelola kelasnya sehingga hasil belajar siswa ada pada tingkat optimal. Peranan guru dalan proses belajar-mengajar antara lain:

\section{Guru sebagai Sumber Belajar}

Peran guru sebagai sumber belajar merupakan peran yang sangat penting dan berkaitan erat dengan penguasaan materi pelajaran. Dikatakan guru yang baik manakala ia dapat menguasai materi. Materi yang terdapat dalam pembelajaran matematika mulai dari tingkat yang mudah sampai kepada yang sukar. Dengan demikian, guru matematika harus benar-benar mampu menguasai materi yang akan diajarkan kepada peserta didik sehingga tujuan pembelajaran tercapai.

\section{Guru sebagai Demonstrator}

Guru sebagai demonstrator adalah peran untuk mempertunjukkan kepada siswa segala sesuatu yang dapat membuat siswa lebih mengerti dan memahami setiap pesan yang disampaikan. Dalam pembelajaran matematika guru mempertunjukkan dan menginformasikan langkah-lang-

2 Hamzah B.Uno dan Masri Kuadrad, Mengelola kecerdasan dalam Pembelajaran (Jakarta: Bumi Aksara, 2010), hlm.110. 
kahnya setiap materi yang disampaikan kepada siswa sampai siswa dapat memahaminya. Contonya, pada materi lingkaran: langkah pertama guru menunujukkan benda di kelas yang berbentuk lingkaran, dan langkah kedua guru menyebutkan unsur-unsutr yang ada pada lingkaran dan sampai siswa paham dan mengerti.

\section{Guru sebagai Pengelola Kelas}

Dalam perannya sebagai pengelola kelas (learning manager) guru hendaknya mampu mengelola kelas karena kelas merupakan lingkungan belajar serta merupakan suatu aspek dari lingkungan sekolah yang perlu di organisasi. Lingkungan ini diatur dan diawasi agar kegiatan-kegiatan belajar terarah kepada tujuan pembelajaran matematika.

\section{Guru sebagai fasilitator}

Sebagai fasilitator guru berperan dalam memberikan pelayanan untuk memudahkan siswa dalam kegiatan belajar-mengajar. Dalam kegiatan proses belajar matematika di kelas guru harus menyediakan alat serta bahan maupun media sebagai pendukung terlaksananya kegiatan belajar-mengajar.

\section{Guru sebagai Pembimbing}

Peran guru dalam membimbing siswa yaitu agar dapat menemukan berbagai potensi yang dimiliki siswanya sebagai bekal hidup mereka dan dapat mencapai dan melaksanakan tugas-tugas perkembangan mereka, sehingga dengan ketercapaian itu dapat tumbuh dan berkembang sebagai manusia ideal yang menjadi harapan orangtua.

\section{Guru sebagai Motivator}

Dalam proses belajar matematika tidak semua siswa terdorong hatinya untuk serius mengikuti pembelajaran, ini diakibatkan oleh motivasinya yang sangat kurang dalam meningkatkan pengetahuannya. Dalam hal ini, tugas seorang guru matematika menumbuhkan motivasi dalam diri anak agar terdorong hatinya untuk berbuat dalam meningkatkan pengetahuannya maupun keterampilannya.

\section{Guru sebagai Evaluator}

Untuk mengetahui sejauh mana tingkat pencapaian siswa seorang guru matematika hendaknya melaksanakan evaluasi, selain itu juga yang 
terpenting untuk mengukur tingkat keberhasilan seorang guru dalam mencapai indikator hasil belajar. Sehubungan dengan itu, seorang guru yang mengajarkan matematika hendaknya memberikan evaluasi baik lisan maupun tulisan.

\section{Keterampilan Dasar Mengajar Guru Matematika}

Keterampilan dasar mengajar bagi guru matematika diperlukan agar guru dapat melaksanakan perannya dalam pengelolaan proses pembelajaran, sehingga pembelajaran dapat berjalan secara efektif dan efesien. Dalam hal ini, terdapat 8 (delapan) keterampilan yang dapat digunakan guru selama proses belajar-mengajar yaitu; keterampilan bertanya, keterampilan memberikan penguatan, keterampilan mengadakan variasi, keterampilan menjelaskan, keterampilan membuka dan menutup pelajaran, keterampilan membimbing diskusi kelompok kecil, keterampilan mengelola kelas, keterampilan mengajar kelompok kecil dan perseorangan.

\section{Keterampilan Dasar Bertanya}

Keterampilan bertanya merupakan ucapan guru secara verbal yang meminta respon dari peserta didik. Respon yang diberikan dapat berupa pengetahuan sampai hal-hal yang merupakan hasil pertimbangan. Dengan demikian, bertanya merupakan stimulus efektif yang mendorong kemampuan berpikir peserta didik. ${ }^{3}$ Ada beberapa fungsi pertanyaan dalam proses belajar-mengajar di antaranya:

a. Memberikan motivasi kepada siswa untuk berpikir dan memecahkan masalah dengan kemampuan sendiri.

b. Memberikan motivasi kepada siswa untuk berperan aktif dalam proses belajar-mengajar.

c. Membangkitkan minat dan rasa ingin tahu siswa terhadap suatu masalah yang dihadapi atau dibicarakan.

d. Menuntun proses berpikir siswa karena dengan pertanyaan-pertanyaan yang baik dapat membantu siswa untuk menentukan jawaban yang baik

3Jamal Ma'mur Asmani, Micro Teacing Team (Yokyakarta: Diva Press, 2010), hlm. 29. 
e. Memusatkan perhatian siswa terhadap siswa yang di bahas. ${ }^{4}$

Dalam proses belajar-mengajar, bertanya memainkan peranan penting sebab pertanyaan yang tersusun dengan baik dan teknik pelontaran yang tepat akan memberikan dampak positif. Pertanyaan yang baik di bagi menjadi dua jenis, yaitu: pertanyaan menurut maksudnya, dan pertanyaan menurut Taksonomi Bloom.

Pertanyaan menurut maksudnya terdiri atas: pertanyaan permintaan (compliance question), pertanyaan retoris (rhetorical question), pertanyaan mengarahkan atau menuntun (prompting question) dan pertanyaan menggali (probing question). Pertanyaan menurut Taksonomi Bloom, yaitu: pertanyaan pengetahuan (recall question atau knowlagde question), pemahaman (comprehention question), pertanyaan penerapan (application question), pertanyaan sintetis (synthesis question), dan pertanyaan evaluasi (evaluation question).

Untuk meningkatkan partisipasi siswa dalam proses belajarmengajar, guru perlu menunjukkan sikap yang baik pada waktu mengajukan pertanyaan maupun ketika menerima jawaban siswa. Siswa juga harus menghindari kebiasaan seperti: menjawab pertanyaan sendiri, mengulang jawaban siswa, mengulang pertanyaan sendiri, mengajukan pertanyaan dengan jawaban serentak, menentukan siswa yang harus menjawab sebelum bertanya dan mengajukan pertanyaan ganda.

Dalam proses belajar-mengajar setiap pertanyaan, baik berupa kalimat tanya atau suruhan yang menuntut respons siswa sehingga dapat menambah pengetahuan dan meningkatkan kemampuan berpikir siswa, dimasukkan dalam golongan pertanyaan. Keterampilan bertanya dibedakan atas keterampilan bertanya dasar dan keterampilan bertanya lanjut. Keterampilan bertanya dasar mempunyai beberapa komponen dasar yang perlu diterapkan dalam mengajukan segala jenis pertanyaan. Komponenkomponen yang dimaksud adalah: pengungkapan pertanyaan secara jelas dan singkat, pemberian acuan, pemusatan, pemindah giliran, penyebaran, pemberian waktu berpikir dan pemberian tuntunan.

${ }^{4}$ Ahmad Sabri, Strategi Belajar-Mengajar dan Mikro Teaching (Jakarta: Ciputat Press, 2005), hlm. 82-83. 
Sedangkan keterampilan bertanya lanjut merupakan lanjutan dari keterampilan bertanya dasar yang lebih mengutamakan usaha mengembangkan kemampuan berpikir siswa, memperbesar pertisipasi dan mendorong siswa agar dapat berinisiatif sendiri. Keterampilan bertanya lanjut dibentuk atas landasan penguasaan komponen-komponen bertanya dasar. Karena itu, semua komponen bertanya dasar masih dipakai dalam penerapan keterampilan bertanya lanjut. Adapun komponen-komponen bertanya lanjut itu adalah: pengubahan susunan tingkat kognitif dalam menjawab pertanyaan, pengaturan urutan pertanyaan, penggunaan pertanyaan pelacak dan peningkatan terjadinya interaksi.

\section{Keterampilan Memberi Penguatan}

Penguatan (reinforcement) pada dasarnya adalah suatu respon yang diberikan terhadap prilaku atau perbuatan baik yang dapat memacu terulangnya perbuatan tersebut. Menurut pengertian yang dikemukakan oleh Wina Sanjaya, keterampilan dasar penguatan adalah segala bentuk respon yang merupakan bagian dari modifikasi tingkah laku guru terhadap siswa yang bertujuan untuk memberikan informasi atau unpan balik atas perbuatan atau respon siswa. ${ }^{5}$

Ada dua jenis penguatan yang diberikan oleh guru, yaitu penguatan verbal dan non verbal. ${ }^{6}$

a. Penguatan verbal

Penguatan verbal adalah penguatan yang diungkapkan dengan kata-kata baik, kata-kata pujian dan penghargaan atas kata-kata koreksi. Melalui kata-kata itu siswsa akan merasa puas dan terdorong untuk lebih aktif belajar. Misalnya ketika diajukan sebuah pertanyaan kemudian siswa menjawab dengan tepat, maka guru menmuji siswa tersebut dengan mengatakan "bagus sekali", "tepat sekali", "wah hebat kamu" dan sebagainya.

5Dadang Sukirman, Micro Teacing, Wajaj Bahaunar Shidiq, hlm. 307.

6Wina Sanjaya, Pembelajaran dalam Implementasi Kurikulum Berbasis Kompetensi (Jakarta: Kencana, 2005), hlm. 164-165. 
b. Penguatan non verbal

Penguatan non verbal adalah penguatan yang diungkapkan melalui bahasa isyarat dan memberikan tanda-tanda tertentu. Adapun jenis-jenis respon (penguatan) yang digolongkan kedalam penguatan non verbal antara lain sebagai berikut:

1) Mimik dan gerakan badan

Mimik dan gerakan yang dilakukan guru seperti: mengekspresikan wajah ceria, senyuman, anggukan kepala, menggunakan ibu jari, tepukan tangan dan gerakan badan lainnya.

2) Gerakan mendekati

Gerakan mendekati dilakukan guru dengan cara menghampiri siswa dan bahkan duduk bersama-sama dengan siswa. Pada saat guru mendekati siswa merasa diperhatikan sehingga siswa akan merasa senang dan aman.

3) Sentuhan

Penguatan dalam bentuk sentuhan dilakukan dengan adanya kontak fisik antara guru dengan siswa (gesturing). Misalnya berjabatan tangan, menepuk, mengelus anggota-anggota badan yang dianggap tepat dan bentuk lain yang sejenis.

4) Kegiatan yang menyenangkan

Untuk meningkatkan perhatian dan motivasi belajar, guru dapat melakukan penguatan dengan cara memberi kesempatan kepada siswa untuk mengekspresikan kemampuannya sesuai dengan minat, bakat, dan kemampuannya.

5) Pemberian simbol atau benda

Simbol adalah tanda-tanda yang diberikan atau dilakukan guru terkait dengan perilaku belajar siswa.

6) Penguatan tak penuh

Penguatan tak penuh yaitu respon atau sebagian prilaku belajar siswa yang belum tuntas. ${ }^{7}$

7Dadang sukirman, Loc. Cit. hlm. 312-316. 


\section{Keterampilan Memberikan Variasi}

Keterampilan memberikan variasi merupakan suatu proses pengubahan dalam pengajaran yang menyangkut 3 (tiga) komponen, yaitu variasi dalam gaya mengajar, variasi media dan bahan lain, dan variasi interaksi. 8 Komponen-komponen mengadakan variasi ada 3 (tiga) bagian yaitu:

1) Variasi dalam gaya mengajar guru

a. Penggunaan variasi suara (teacher voice)

b. Pemusatan perhatian (focusing)

Dalam pemusatan perhatian dapat dibedakan 6 (enam) macam yaitu:

(a) Verbal focusing yakni pemusatan perhatian melalui kata-kata seperti: coba dengarkan,, amati baik baik gambar ini atau periksa gambar ini dengan seksama.

(b) Gestural focusing yaitu pemusatan perhatian melalui syarat tertentu, seperti menunjukkan pada gambar yang tergantung di dingding atau di papan tulis.

(c) Kesenyapan atau kebisuan guru (teaching silence)

Dalam hal ini guru sengaja dan tiba-tiba menciptakan atau menimbulkan kesenyapan atau kebisuan sejenak selagi menerangkan sesuatu bahan kepada murid.

(d) Mengadakan kontak pandang dengan gerakan (eye contac and movement)

Apabila guru berinteraksi dengan murid, sebaiknya pandangan menjelajahi seluruh kelas dan melihat kepada mata murid-murid.

(e) Gerakan badan dan mimic

Variasi ini menyangkut ekspresi wajah guru, gerak kepala, dan gerak badan.

(f) Pergantian posisi dalam kelas (teacher movement)

2) Variasi media dan bahan ajar

Ada tiga komponen dalam variasi penggunaan media, yaitu:

(a) Variasi media pandang

8Haibuan dkk, Proses Belajar-Mengajar, Keterampilan Dasar Pengajaran Micro (Bandung: Remaja Rosda Karya,1994), hlm. 70-71. 
Penggunaan media pandang seperti: buku, majalah, globe, peta majalah dinding, film, tv dan lain-lain.

(b) Variasi media dengar

(c) Variasi media taktil

Maksudnya memberikan kesempatan kepada anak didik untuk menyentuh dan memanipulasi benda atau bahan ajar.

3) Variasi interaksi

Variasi dalam pola interaksi antara guru dengan anak didiknya memiliki rentangan yang bergerak dari dua kutub yaitu:

(a) Anak didik bekerja atau belajar secara bebas tanpa campur tangan dari guru.

(b) Anak didik mendengarkan dengan pasif, situasi didominasi guru.

\section{Keterampilan Membuka dan Menutup Pelajaran}

Membuka pelajaran atau set induction adalah usaha yang dilakukan guru dalam kegiatan pembelajaran untuk menciptakan prakondisi bagi siswa agar mental maupun perhatian terpusat pada pengalaman belajar, sehingga materi yang disajikan akan mudah mencapai kompetensi yang diharapkan. Komponen-komponen yang berkaitan dengan membuka pelajaran meliputi:

a. Menarik perhatian peserta didik.

Banyak cara yang dapat dilakukan guru untuk menarik perhatian peserta didik terhadap pelajaran yang akan disajikan yaitu melalui gaya mengajar guru dan menggunakan media dan sumbetr belajar yang bervariasi.

b. Membangkitkan motivasi

Cara yang dilakukan guru untuk membangkitkan motivasi belajar peserta didik yaitu, kehangatan dan semangat, membangkitkan rasa ingin tahu, mengemukakan ide yang bertentangan, memperhatikan minat belajar peserta didik.

c. Memberikan acuan

Dalam memberi acuan dapat dilakukan seperti: mengemukakan tujuan dan batas-batas tugas, menyarankan langkah-langkah yang akan dilakukan, mengingatkan masalah pokok, mengajukan pertanyaan. 
d. Membuat kaitan

Cara yang dapat dilakukan guru antara lain: mengajukan pertanyaan apersepsi, mengulas sepintas garis besar isi pembelajaran yang telah lalu, mengaitkan materi yang diajarkan dengan lingkungan peserta didik, menghubung-hubungkan bahan pelajaran yang sejenis dan berurutan. ${ }^{9}$

Menutup pelajaran (closing) adalah kegiatan yang dilakukan oleh guru untuk mengakhiri pelajaran atau kegiatan belajar-mengajar. ${ }^{10}$ Bentuk usaha guru dalam mengakhiri kegiatan belajar-mengajar adalah sebagai berikut:

1) Merangkum atau membuat garis-garis besar persoalan yang baru di bahas atau dipelajari sehingga siswa memperoleh gambaran yang jelas tentang makna serta esensi pokok persoalan yang baru saja diperbincangkan.

2) Mengonsolidasikan perhatian siswa terhadap hal-hal pokok dalam pembelajaran yang bersangkutan agar informasi yang telah diterimanya dapat membangkitkan minat dan kemampuannya terhadap pelajaran selanjutnya.

3) Mengorganisasi semua kegiatan atau pelajaran yang telah dipelajari sehingga merupakan suatu kebutuhan yang berarti dalam memahami materi yang baru dipelajari.

4) Memberikan tindakan lanjut (follow up) berupa saran-saran dan ajakan agar materi yang baru dipelajari jangan dilupakan, dan agar dipelajari kembali ke rumah.

\section{Keterampilan Menjelaskan}

Dalam kaitan dengan kegiatan belajar-mengajar atau pelatihan, menjelaskan berarti mengorganisasikan materi pelajaran dalam tata urutan yang terencana secara sistematis, sehingga dengan mudah dapat dipahami siswa. ${ }^{11}$

9E. Mulyasa, Menjadi Guru Profesional Menciptakan Pembelajaran Kreatif dan Menyenangkan (Bandung: Remaja Rosda Karya, 2008), hlm. 85-88.

${ }^{10} \mathrm{M}$. Uzer Usman, Menjadi Guru Profesional (Bandung: Remaja Rosda Karya, 1989), hlm. 84.

${ }^{11}$ Erman Suherman, dkk, Strategi Pembelajaran Matematika Kontemporer (Bandung: UPI, 2003), hlm. 
Keterampilan menjelaskan terdiri dari atas berbagai komponen sebagai berikut:

1) Komponen merencanakan penjelasan mencakup:

(a) Isi pesan (pokok-pokok materi yang dipilih dan disusun secara sistematis di sertai dengan contoh-contoh

(b) Hal-hal yang berkaitan dengan karakteristik penerima pesan siswa

2) Komponen menyajikan penjelasan sebagai berikut:

(a) Kegiatan yang dapat dicapai dengan berbagai cara seperti: bahasa yang jelas, berbicara yang lancar, mendefenisikan istilah-istilah yang teknis dan berhenti sejenak untuk melihat respon siswa.

(b) Penggunaan contoh dan ilustrasi yang dapat mengikuti pola pikir induktif dan deduktif.

(c) Pemberian tekanan pada bagian-bagian yang penting dengan cara penekanan suara, membuat iktisar dan mengemukakan tujuan.

(d) Balikan tentang penjelasan yang disajikan melihat mimik siswa atau pengajuan pertanyaan.

\section{Keterampilan Mengelola Kelas}

Keterampilan mengelola kelas adalah keterampilan dalam menciptakan dan mempertahankan kondisi kelas yang optimal guna terjadinya proses mengajar yang serasi dan efektif. Komponen dalam mengelola kelas sebagai berikut:

1) Keterampilan yang berhubungan dengan penciptaan dan pemeliharaan kondisi belajar yang optimal. Penciptaan pemeliharaan kondisi yang optimal dapat dilakukan sebagai berikut: menunujukkan sikap tanggap, membagi perhatian secara visual dan verbal, memusatkan perhatian, memberi petunjuk-petunjuk yang jelas, menegur secara bijaksana dan sebagainya.

2) Keterampilan yang berhubungan denga pengendalian kondisi belajar yang optimal. Keterampilan ini berkaitan dengan respon guru terhadap gangguan siswa yang berkelanjutan dengan maksud agar guru dapat mengadakan tindakan remedial untuk mengembalikan kondisi belajar yang optimal. 


\section{Keterampilan Membimbing Diskusi Kelompok Kecil}

Diskusi kelompok adalah suatu proses yang teratur yang melibatkan sekelompok orang dalam interaksi tatap muka yang informal dengan berbagai pengalaman atau informasi, pengampilan keputusan, atau pemecahan masalah. Komponen-komponen keterampilan membimbing diskusi sebagai berikut:

1) Memusatkan perhatian siswa pada tujuan dan topik diskusi.

Caranya: rumuskan tujuan dan topik yang akan dibahas, kemukakan masalah-masalah khusus, catat perubahan atau penyimpangan.

2) Memperjelas masalah atau urunan pendapat

3) Menganalisis pandangan siswa

4) Meningkatkan urunan siswa

5) Menyebarkan kesempatan berpartisipasi

6) Menutup diskusi

7) Hal-hal yang harus dihindari.

8. Keterampilan Mengajar Kelompok Kecil dan Perseorangan

1) Prinsif dan tujuan

Mengajarkan kelompok kecil dan perseorangan terjadi dalam konteks pengajaran klasikal. Di dalam kelas seorang guru mungkin menghadapi banyak kelompok kecil serta banyak siswa, yang masingmasing diberi kesempatan belajar secara berkelompok atau perseorangan. Penguasaan keterampilan mengajar kelompok kecil dan perseorangan memungkinkan guru mengelola jenis kegiatan ini secara efektif dan efesien serta memainkan perannya sebagai:

(a) Organisator kegiatan belajar-mengajar

(b) Sumber informasi bagi siswa

(c) Motivator bagi siswa untuk belajar

(d) Penyedia materi dan kesempatan belajar bagi siswa

(e) Pendiagnosa dan pemberi bantuan bagi yang membutuhkan.

2) Komponen keterampilan

Ada 4 (empat) kelompok keterampilan yang perlu dikuasai oleh guru, dalam kaitan ini sebagai berikut:

(a) Keterampilan mengadakan pendekatan secara pribadi 
(b) Keterampilan mengorganisasikan

(c) Keterampilan membimbing dan memudahkan belajar

(d) Keterampilan merencanakan dan melaksanakan kegiatan belajarmengajar.

3) Prinsip penggunaan

(a) Variasi pengorganisasian kelas besar, kelompok perorangan tujuan yang hendak dicapai, kemampuan siswa, ketersediaan fasilitas, waktu serta kemampuan guru.

(b) Tidak semua topik dapat dipelajari secara efektif dalam kelompok kecil dan perseorangan.

(c) Pengajaran kelompok kecil yang efektif selalu diakhiri dengan suatu kulminasi berupa rangkuman, pemantapan, kesepakatan laporan, dan sebagainya.

(d) Guru perlu mengenal siswa secara perseorangan agar dapat mengatur kondisi belajar dengan tepat.

(e) Dalam kegiatan belajar perseorangan siswa dapat bekerja secara bebas dengan bahan yang disiapkan.

\section{Penutup}

Seorang guru matematika ketika hendak melaksanakan proses belajar-mengajar seharusnya sudah memahami dan dapat menerapkan keterampilan-keterampilan dasar mengajar. Keterampilan-keterampilan tersebut diperoleh dari latihan-latihan keguruan. Keterampilan-keterampilan itu juga perlu dipelajari oleh guru, agar ia mampu melaksanakan fungsi pengajaran secara optimal. Seorang guru bukan saja mentrasferkan ilmu pengetahuan kepada anak didik, tetapi harus mengetahui langkah-langkah untuk mencapai tujuan pengajaran. Dengan kata lain, guru, setidaknya, harus menguasai 8 (delapan) keterampilan dasar mengajar, yaitu keterampilan bertanya, keterampilan memberikan penguatan, keterampilan mengadakan variasi, keterampilan menjelaskan, keterampilan membuka dan menutup pelajaran, keterampilan membimbing diskusi kelompok kecil, keterampilan mengelola kelas, keterampilan mengajar kelompok kecil dan perseorangan. 


\section{Daftar Pustaka}

Ahmad Sabri, Strategi Belajar-Mengajar dan Micro Teaching, Jakarta: Ciputat Press, 2005.

Dadang Sukirman, Micro Teaching, Wajaj Bahaunar Shidiq.

E. Mulyasa, Menjadi Guru Profesional Menciptakan Pembelajaran Kreatif dan Menyenangkan, Bandung: Remaja Rosda Karya, 2008.

Hamzah B.Uno dan Masri Kuadrad, Mengelola Kecerdasan dalam Pembelajaran, Jakarta: Bumi Aksara, 2010.

Erman Suherman, dkk, Strategi Pembelajaran Matematika Kontemporer, Bandung: UPI, 2003.

Hasibuan, dkk, Proses Belajar-Mengajar, Keterampilan Dasar Pengajaran Micro, Bandung: Remaja Rosda Karya,1994.

Jamal Ma'mur Asmani, Micro Teaching Team, Yokyakarta: Diva Press, 2010.

Muhammad Surya, Membangun Manusia Profesioalisme Guru, Makalah Seminar Pendidikan, Jakarta, 6 Mei 2005.

Usman Uzer, Menjadi Guru Profesional, Bandung: Remaja Rosda Karya, 1989.

Wina Sanjaya, Pembelajaran dalam Implementasi Kurikulum Berbasis Kompetensi, Jakarta: Kencana, 2005. 